\title{
直方体ピンを用いた異方複曲面のピーン成形
}

\section{Peen forming using rectangular solid pins for anisotropic double-curved surface}

\author{
Takahiro OHTA $^{* 1}$, Akira KONO ${ }^{* 2}$ and Takashi KOZAKI ${ }^{* 3}$ \\ ${ }^{{ }_{1} 1}$ School of engineering, Tokai university \\ 4-1-1 Kitakaname, Hiratsuka-shi, Kanagawa 259-1292, Japan \\ ${ }^{* 2}$ Research \& Innovation Center, Mitsubishi Heavy Industries, Ltd. \\ 10 Oye-cho, Minato-ku, Nagoya-shi, Aichi 455-8515, Japan \\ ${ }^{* 3}$ Commercial Aviation \& Transportation Systems, Mitsubishi Heavy Industries, Ltd. \\ 10 Oye-cho, Minato-ku, Nagoya-shi, Aichi 455-8515, Japan
}

Received: 21 September 2016; Revised: 19 January 2017; Accepted: 19 April 2017

\begin{abstract}
Peen forming has been widely used in the aerospace industry for forming complex components of large thin wings. The conventional peen forming using spherical shots shows a tendency to form the spherical surface because of its axisymmetric plastic strain. In this study, a new peen forming method using rectangular solid pins is developed. It is possible to produce the different distribution between $x$ direction (short side of pin) plastic strain and $z$ direction (long side of pin) plastic strain. The anisotropic plastic strain distribution causes smaller curvature radius of $x$ direction section than that of $z$ direction section. In order to verify the anisotropic plastic strain distribution in this method, the effects of pin tip shape are analyzed by dynamic explicit finite element method. The ratios of $x$ direction plastic strain to $z$ direction plastic strain increase with decreasing pin tip radius. It is confirmed that anisotropic double-curved surfaces are produced by drop tests using multi- rectangular-solid pins.
\end{abstract}

Key words : Plastic working, Shot peening, Finite element method (FEM), Aluminum alloy, Incremental forming, Dieless forming

\section{1. 緒言}

ショットピーニングは鋼球を金属表面に打ち付けることで，金属表面に圧縮残留応力を導入する技術である. 簡便に疲労強度を向上することができるため，自動車産業や航空機産業で幅広く採用されている．ショットピー ニングは金属表面に圧縮残留応力を与えるだけでなく，成形にも採用されている，ピーン成形は数 $\mathrm{mm}$ のショットを外板表面に衝突させ，ごく表面を伸ばすことにより，金属を曲げる手法である。航空機の主翼外板 は大型で複雑な形状をしているため，ピーン成形が適用されている（Kopp et al., 1993），(高橋他，2007）,

(Yamada et al., 2002). 航空製品は典型的な多種少量生産製品であるため，ダイレス成形が広く用いられている. ピーン成形は型を必要としない成形であり，究極のダイレス成形である.

近年，航空機も然費向上が重要で，主翼の形状は複雑化が進んでおり，流体力学から求められる球面，鞍型，

No.16-00451 [DOI:10.1299/transjsme.16-00451], J-STAGE Advance Publication date: 8 May, 2017

*1 正員, 東海大学工学部動力機械工学科 (厂259-1292 神奈川県平塚市北金目 4-1-1)

*2 三菱重工業 (株) 総合研究所製造研究部（干455-8515 愛知県名古屋市港区大江町 10$)$

*3 三菱重工業 (株) 交通・輸送ドメイン 部品工作部

E-mail of corresponding author: takahiro_ohta@tsc.u-tokai.ac.jp 
単曲面に近い形状など複雑な形状で形成されている。しかし，球を用いたピーン成形では発生するひず みは図 1(a)に示すように軸対称 $\left(x\right.$ 方向塑性ひずみ $\varepsilon_{x}$ と $z$ 方向塑性ひずみ $\varepsilon_{z}$ が同じ $)$ であり, 変形も球面 $(x$ 方向 曲率半径 $R_{x}$ と $z$ 方向曲率半径 $R_{z}$ が同じ） となる傾向がある. 従来のピーン成形では種々の形状に対応寸るため, マスキングを行ってピーニング領域を限定したり，場所ごとに異なるサイズのショットを用いており，成形準備 に時間がかかっている（Baughman，1970)，(Clausen and Bruder，1987)。また，単曲面に近い形状では，主翼外 板に予め応力を付与して曲げた状態でピーニングを行うストレスピーン成形が適用されている（Li， 1981）,

(Miao et al., 2010). 主翼に応力を付与することは治具の設置など多大な時間が必要で, 成形時間が増加する要 因となっている.

最近では超音波ピーニング（Ultrasonic Peening：USP）でピンを用いた手法もピーン成形に適用されている（黒 井他, 2010). 超音波ピーニングではピンにガイドを設けることで, 円形以外のピンの適用も可能である. 直方体 ピンを用いたピーニングでは図 1(b)に示すように， $x$ 方向（長方体ピンの短辺方向）塑性ひずみ $\varepsilon_{x}$ と $z$ 方向（長 方体ピンの長辺方向）塑性ひずみ $\varepsilon_{\mathrm{z}}$ の大きさを変化させることが可能で, 成形形状の $x$ 方向曲率半径 $R_{x}$ と $z$ 方向 曲率半径 $R_{z}$ が異なる異方性を持った成形形状を得られる可能性がある. エアハンマーに一つの棈円形のピンを取 り付けて，板をピーニングすることで $R_{x}$ と $R_{z}$ を制御する方法も提案されている (Kopp, 1984). 超音波ピーニン グでは複数のピンを用いて，効率よくピーニングできるため，民間航空機主翼のピーン成形に適していると考え られる，そこで，本研究では直方体ピンを用いた場合に塑性ひずみの異方性を与えるピン先端形状を有限要素 法を用いた解析で決定した. 次に, 複数の直方体ピンを用いた落下試験により，USP を用いた成形曲率半径に異 方性 $\left(R_{x}<R_{z}\right)$ の付与の可能性を検討した.

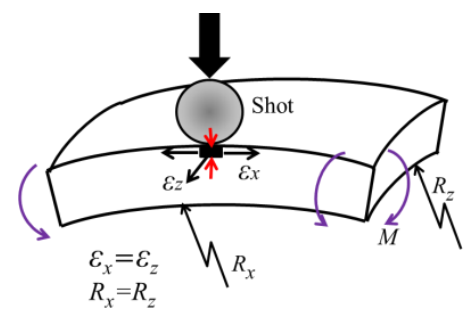

(a) Sphere balls

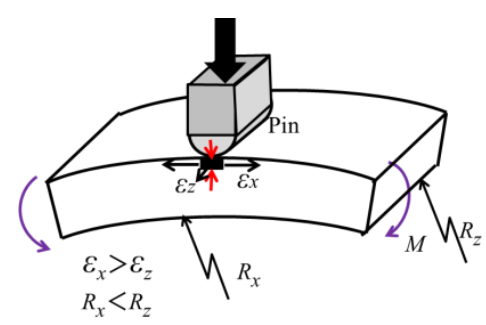

(b) Rectangular solid pins

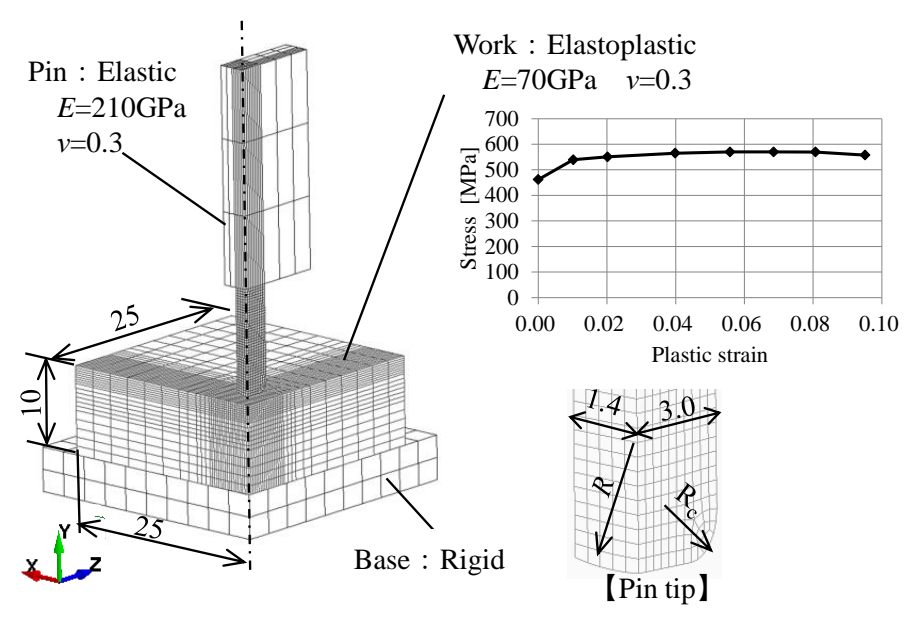

Fig. 2 Analysis model.

\section{2. 解析方法}

USP に適用できる直方体ピン形状において, $\varepsilon_{x}>\varepsilon_{z}$ が成立することを確認するため, ピンの先端形状を変えて， 数值解析を行った．ピーン成形はピーニングされた表面近傍に発生する引張の塑性ひずみにより板を曲げる手法 であり，塑性ひずみ量と成形曲率半径には密接な関係がある（高橋他，2007）。USPにおいては複数のピンが設 置された装置を試験体表面で走查して，全面にピーニングを行うが，本研究ではピン先端形状の影響を評価する ことを目的に, 単体ピン直下の塑性ひずみの分布のみを評価した. 解析には動的陽解法有限要素法コード LS-Dyna ver.741 を用いた. 解析モデルを図 2 に示寸. 対称性を考慮して $1 / 4$ でモデル化した. ピンは弾性体 (ヤング率 $E$ : 210GPa, ポアソン比 $v: 0.3$, 密度: $7.8 \times 10^{-6} \mathrm{~kg} / \mathrm{mm}^{3}$ ), ベースは剛体とした. 試験体はアルミニウム合金(A7075-T651) 
Ohta, Kono and Kozaki, Transactions of the JSME (in Japanese), Vol.83, No.849 (2017)

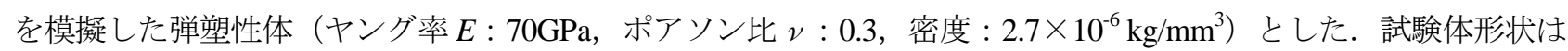
板厚 $10 \mathrm{~mm}$ で，板幅と長さは $50 \mathrm{~mm}$ である. 試験体の板厚は民間航空機主翼で最も板厚が厚い部位を想定して決 定した．材料モデルは図 2 に示寸多直線近似の等方硬化材を用いた. 用いた要素タイプは 8 節点低減積分ソリッ ド要素である. 要素はピンと接触する範囲近傍では, $0.25 \times 0.25 \times 0.25 \mathrm{~mm}$ とした．試験体とピンの摩擦はクーロ ン摩擦とし, 摩擦係数は潤滑剤を使用していない場合の代表的な值として 0.2 とした. USP では投射速度は $18 \mathrm{~m} / \mathrm{s}$ 以下でばらつきを持ち，多くは $6 \mathrm{~m} / \mathrm{s}$ 以下であることが実験結果や解析結果から報告されている（Rousseau et al., 2015), (Thuemmler et al., 2008)，(太田，2017）。そこで, ピンに初速度 $5 \mathrm{~m} / \mathrm{s}$ を与え, 1 回の衝突について解析 を実施した. 重力の影響は考慮していない. 動的陽解法であり, 衝突後の塑性ひずみはわずかに振動するため, 平均值を残留塑性ひずみとした．ピン先端の短辺は $2.8 \mathrm{~mm}$ ，長辺は $6 \mathrm{~mm}$ である．ピンの短辺と長辺の長さによ って, 発生する塑性ひずみの異方性に差が生じる可能性があるが, ピンの形状は USP 装置の制約から決定し, 本 研究では固定とした. 形状パラメータとして, 先端半径 $R$ と先端面取り半径 $R_{c}$ を設定した (図 2 参照). ピンの 全体積は $R$ と $R_{c}$ でわずかに変化するが, 約 $3209 \mathrm{~mm}^{3}$ である.

\section{3. 解析結果}

ピンの先端半径 $R$ を変化させた場合の中心での $y$ 軸方向 (板厚方向) の塑性ひずみ $\varepsilon_{x}$ と $\varepsilon_{z}$ の分布を図 3 に示す. 塑性ひずみは要素中心（積分点）での值を出力した， $R_{c}$ は $1 \mathrm{~mm}$ で一定である. いずれのケースも $\varepsilon_{x}, \varepsilon_{z}$ ともに引 張ひずみである.メッシュサイズは $0.25 \mathrm{~mm}$ であり, 本解析モデルではいずれのケースも表面から 2 要素目（積 分点位置が $0.375 \mathrm{~mm}$ ）で塑性ひずみは最大となる. また, $\varepsilon_{x}$ は $\varepsilon_{z}$ に比べて大きい. 先端半径 $R$ を変化させた場合, $R$ が小さいほど発生する塑性ひず夕が大きくなる. 表面から梁さ $0.375 \mathrm{~mm}$ において， $\varepsilon_{x}$ と $\varepsilon_{z}$ の比率を見ると， $R=4 \mathrm{~mm}$ では $\varepsilon_{x} / \varepsilon_{z}=4.3, R=8 \mathrm{~mm}$ では $\varepsilon_{x} / \varepsilon_{z}=2.4, R=12 \mathrm{~mm}$ では $\varepsilon_{x} / \varepsilon_{z}=2.6$ であり, $R=4 \mathrm{~mm}$ で発生する塑性ひずみの 異方性が最大となっている.

塑性ひずみが最大である深さ $0.375 \mathrm{~mm}$ での対称面の $z$ 方向（ピン長辺方向）の $\varepsilon_{x}$ と $\varepsilon_{z}$ の分布を図 4 に示す. $R_{c}=1 \mathrm{~mm}$ ではピン底面の平行部の長さは中心から $2 \mathrm{~mm}$ であり, その範囲に塑性ひずみが生じている. $\varepsilon_{x}$ は $R$ が小 さいほど引張ひずみが大きく, $0 \sim 2 \mathrm{~mm}$ の範囲でほぼ均一に導入される. 一方, $\varepsilon_{z}$ は $2 \mathrm{~mm}$ 付近で引張ひずみがピ 一クとなり，その外側に小さな圧縮ひずみが発生する．以上のように先端半径 $R$ を変えることで， $\varepsilon_{x}$ と $\varepsilon_{z}$ の比率 を変化させることが可能であり, ピン直下に異方性を持った塑性ひずみを導入できる.

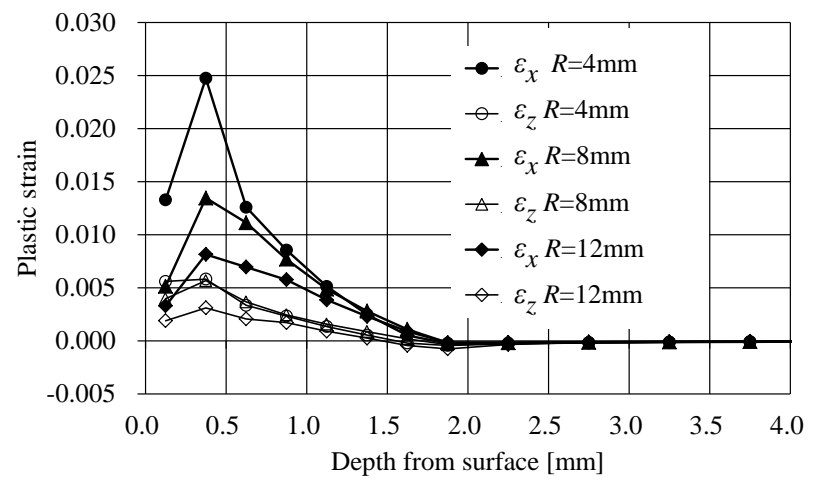

Fig. 3 Effect of tip radius $R$ on plastic strain distribution along $y$ axis in case of $R_{c}=1 \mathrm{~mm}$.

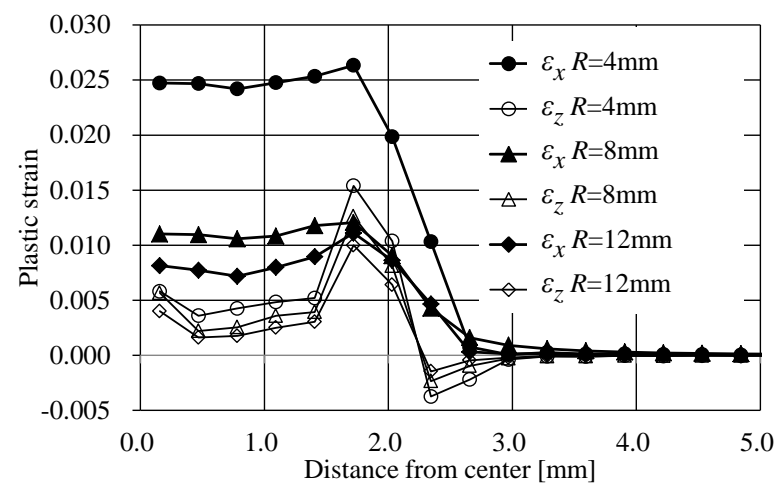

Fig. 4 Effect of tip radius $R$ on plastic strain distribution along $z$ axis at position $0.375 \mathrm{~mm}$ deep from surface in case of $R_{c}=1 \mathrm{~mm}$.

次に，先端面取り半径 $R_{c}$ の影響を解析した．先端半径 $R$ は $4 \mathrm{~mm}$ 一定とした．中心軸 $\mathrm{y}$ 軸方向（板厚方向）の 塑性ひずみ $\varepsilon_{x}$ と $\varepsilon_{z}$ の分布を図 5 に示す. ピン底部の平行部の長さ (1/2 の長さで示す) は, $R_{c}=1 \mathrm{~mm}$ では $2 \mathrm{~mm}$, $R_{c}=1.5 \mathrm{~mm}$ では $1.5 \mathrm{~mm}, R_{c}=2 \mathrm{~mm}$ では $1 \mathrm{~mm}$ である. $R_{c}$ が大きくなると, ピン底部の平行部の長さが短くなるため, ピンと試験体が接触する部分が小さくなる.このため, 同じ衝突速度でも $R_{c}$ が大きい場合は発生する面圧が大き くなる．結果として， $R_{c}$ が大きいほど，板厚内に導入される塑性ひずみは大きくなる，いずれのケースも表面か 
ら深さ $0.375 \mathrm{~mm}$ で塑性ひずみは最大值を示す. 表面から深さ $0.375 \mathrm{~mm}$ において, $\varepsilon_{x}$ と $\varepsilon_{z}$ の比率を見ると, $R_{c}=1 \mathrm{~mm}$ では $\varepsilon_{x} / \varepsilon_{z}=4.3, R_{c}=1.5 \mathrm{~mm}$ では $\varepsilon_{x} / \varepsilon_{z}=5.0, R_{c}=12 \mathrm{~mm}$ では $\varepsilon_{x} / \varepsilon_{z}=4.5$ であり, 発生する塑性ひずみの異方性には. 大 きな差はなく, 平行部の長さの影響は小さい.

深さ $0.375 \mathrm{~mm}$ での対称面表面の $\mathrm{z}$ 方向（ピン長辺方向）の $\varepsilon_{x}$ と $\varepsilon_{z}$ の分布を図 6 に示寸. $\varepsilon_{x}$ はピン底部平行部の 長さの範囲で引張ひずみが発生している， $R_{c}$ が大きいほど, $\varepsilon_{x}$ の引張ひずみは大きい. $\varepsilon_{z}$ はピン底部平行部の終 端付近で引張ひずみが大きくなり，その外側に圧縮ひずみが発生している．また，この終端部付近の引張ひずみ と圧縮ひずみは $R_{c}$ が大きいほど顕著である.

以上の結果から, 先端半径 $R$ が小さい方が圧痕直下のひずみの異方性 $\left(\varepsilon_{x}>\varepsilon_{z}\right)$ が大きくなる. 先端面取り半径 $R_{c}$ については, 同じ運動エネルギーでは $R_{c}$ を大きくすると発生する塑性ひずみ量が大きくなるメリットはあるが, 塑性ひずみの異方性への影響は小さく,かつ, 1 つのピンの施工範囲は $R_{c}$ が大きいほど小さくなる.そこで, $R=4 \mathrm{~mm}$, $R_{c}=1 \mathrm{~mm}$ のピンを試作して検証実験を行うことにした.

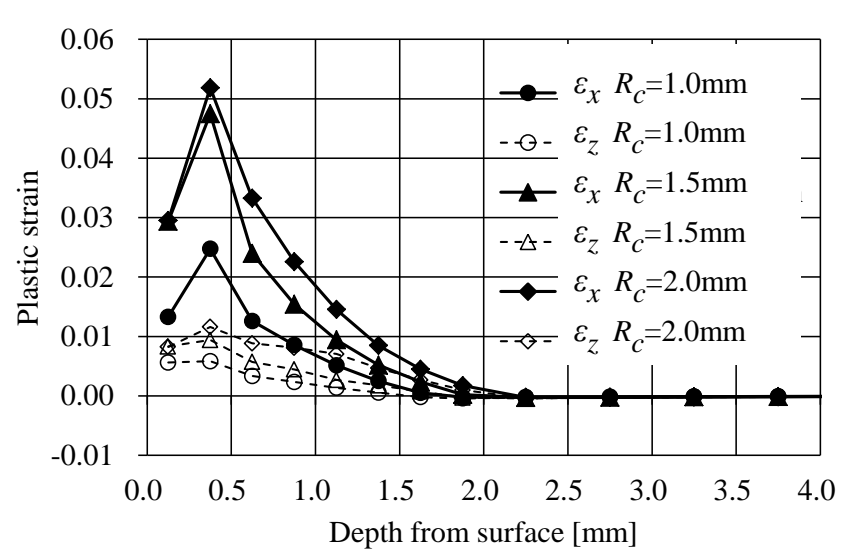

Fig. 5 Effect of tip fillet radius $R_{c}$ on plastic strain distribution along y axis in case of $R=4 \mathrm{~mm}$.

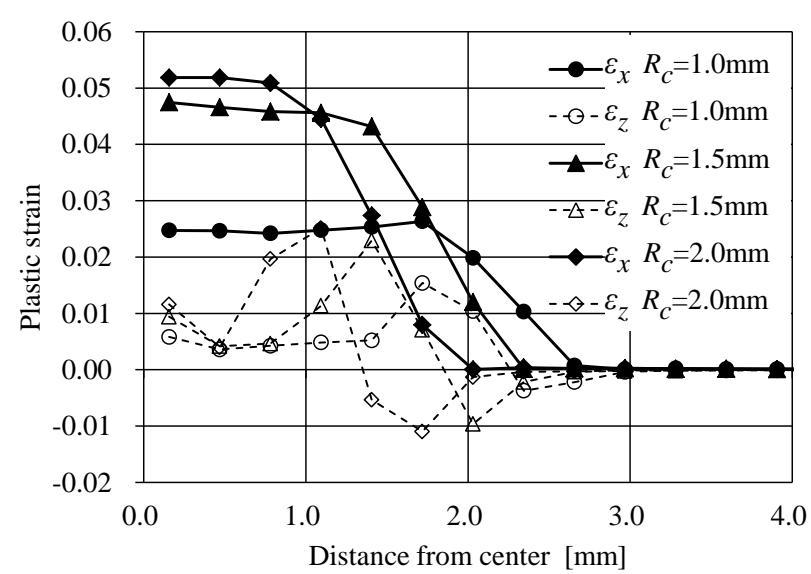

Fig. 6 Effect of tip fillet radius $R_{c}$ on plastic strain distribution along $z$ axis at position $0.375 \mathrm{~mm}$ deep from surface in case of $R=4 \mathrm{~mm}$.

\section{4. 試験装置と試験体}

ピーン成形において直方体ピンを用いることで，成形形状に異方性を与えることを検証するために，簡易な落 下試験を行った。試験に用いた落下装置を図 7 に示す. 装置には複数（最大 45 本）のピンを装着できるように複 数の穴を開けたガイド板を設置する.ピンは図 2 に示したように, この穴に嵌めるように鍔を付けた構造とした. ピンは鍔でガイド板上におかれている状態で落下し, 試験体に衝突すると, 外れて上方に弾き出される. ピンを 保持しているガイド板は試験体に当たる前にストッパで止められるので, 試験体に衝突するのはピンのみである. ピン先端の短辺は $2.8 \mathrm{~mm}$, 長辺は $6 \mathrm{~mm}$, 先端半径 $R$ は $4 \mathrm{~mm}$, 先端面取り半径 $R_{c}$ は $1 \mathrm{~mm}$ で, 質量は $25.2 \mathrm{~g}$ である

(図 2 参照).なお, 運動エネルギーの影響を見るため, 先端は同じ形状で質量が $2.8 \mathrm{~g}$ のピンも製作した. 装置 は最大高さ $2 \mathrm{~m}$ からピンを落下可能である．ピンの材質は炭素鋼（S45C 調質材で $\mathrm{HBW}=201$ 269）である．試 験条件は表 1 に示寸 2 条件で行った．ピンの運動エネルギーは\#1 では $3.7 \times 10^{-1} \mathrm{~J}, \# 2$ では $2.7 \times 10^{-2} \mathrm{~J}$ である. 試 験体は両端面を $z$ 方向に挟んでクランプに固定した. 図 2 に示した解析モデルでは板を Base 上においた状態とし たが，実験では衝突時の反動で試験体が移動するため，クランプで固定することにした．クランプの位置を $x$ 方 向, $z$ 方向に㸚じで移動させることで，試験体全面への落下を可能としている.

落下試験は以下の手順で行った.

Step1 9 列 $\times 3$ 行の 27 個のピンを落下. ピンのピッチは $z$ 方向に $20.4 \mathrm{~mm}$ で, $x$ 方向に $6 \mathrm{~mm}$ である.

Step2 9 列 $\times 2$ 行の 18 個のピンを落下. ピンのピッチは $z$ 方向に $20.4 \mathrm{~mm}$ で, $x$ 方向に $6 \mathrm{~mm}$ である. ピンの位置 は Step1 の位置に対して， $z$ 方向に 10.2mm ずらした位置である. $x$ 方向は Step1 と同じ位置である. Step1 と Step2で合計 45 個のピンを落下させる.この工程を 1 セットとした. 
Step3 全面にピーニングするため, $(x$ 方向 : $1 \mathrm{~mm}$ ピッチで移動 $\times 6$ 回 $) \times （ z$ 方向 : $2 \mathrm{~mm}$ ピッチで移動 $\times 3$ 回 $)$ の計 18 回に対して, Step1 とStep2 を繰り返す.

Step4 Step3 3 回繰り返す.

試験体はアルミニウム合金 A7075-T651 で，0.2\%而力は 537～542MPa，引張強さは 595～599MPa，伸びは 10\% である. 板厚 $10 \mathrm{~mm}$ で形状は 50×50mm である.

Table 1 Drop test conditions.

\begin{tabular}{c|c|c}
\hline \hline Test Number & $\# 1$ & $\# 2$ \\
\hline Tip radius $R[\mathrm{~mm}]$ & 4 & 4 \\
\hline Tip fillet radius $R_{c}[\mathrm{~mm}]$ & 1 & 1 \\
\hline Mass of pin $[\mathrm{g}]$ & 25.4 & 2.8 \\
\hline Drop height $[\mathrm{m}]$ & 1.5 & 1.0 \\
\hline
\end{tabular}

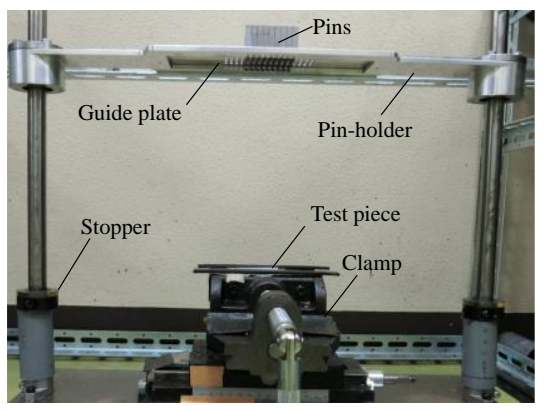

Fig. 7 Drop test equipment.

\section{5. 試験結果}

\section{5・1 デジタル画像相関法によるひずみの計測}

直方体ピンを用いたピーニングにより，異方性 $\left(\varepsilon_{x}>\varepsilon_{z}\right)$ を有したひずみが発生することを確認するため，デジ タル画像相関法 (Digital Image Correlation Method : DIC) を用いた表面ひずみの計測を行った. 計測は ARAMIS 5M

（GOM 社）で実施した。試験は落下高さ $1.5 \mathrm{~m}$ （自由落下速度 : $5.4 \mathrm{~m} / \mathrm{s}$ ）からピン 1 個を落下させて行った。ピ ンは $R=4 \mathrm{~mm}, R_{c}=1 \mathrm{~mm}$ で質量は $25.2 \mathrm{~g}$ である. DIC で計測したひずみのコンター図を図 8 に示す. $\varepsilon_{x}$ は圧痕全体 で引張ひずみが発生している。一方， $\varepsilon_{z}$ は圧痕には大きなひずみは発生しておらず，圧痕の端部に引張と圧縮の ひずみが発生している.この傾向は図 4 の解析結果と一致する. 圧痕中心でのひずみ分布の DIC の計測結果と解 析結果の比較を図 9 に示す。横軸は $z$ 方向の位置を示している. DIC による計測結果では圧痕内で大きなばらつ きが発生しているが，圧痕内では $\varepsilon_{x}$ が $\varepsilon_{z}$ に比べて顕著に大きく，ひずみの異方性 $\left(\varepsilon_{x}>\varepsilon_{z}\right)$ が解析と同様に実験で も確認された.

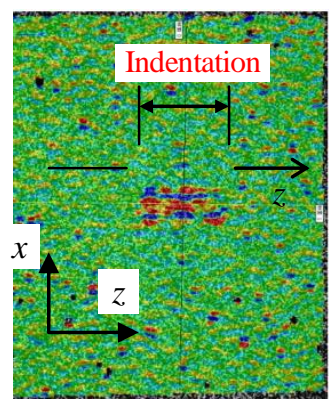

(a) $\varepsilon_{x}$

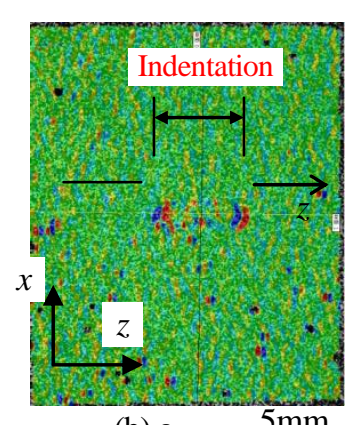

(b) $\varepsilon_{z}$

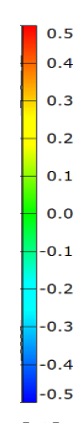

[\%]

Fig. 8 Strain distribution measured by DIC.

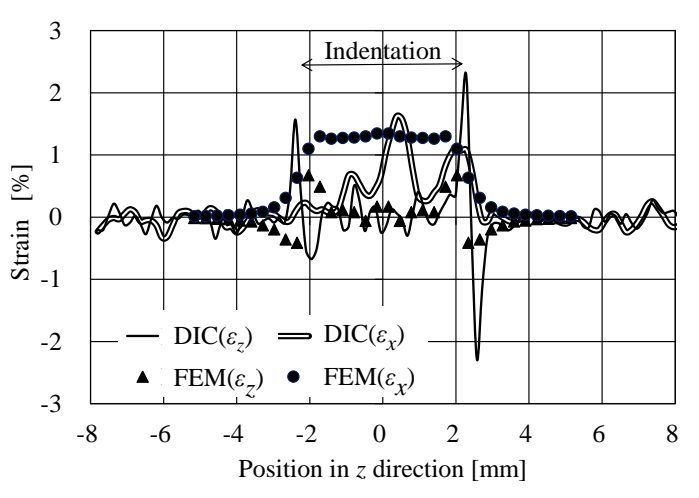

Fig. 9 Strain distribution measured by DIC and analyzed by FEM at center of indication along $z$ axis.

\section{$5 \cdot 2$ 落下試験結果}

図 7 に示した落下試験装置を用いて，複数の穴を開けたガイド板にピンを設置し，落下試験を行った。落下試 験後に接触式の形状計測機で板中央部の形状計測を実施した. 試験後の試験体表面の写真を図 10 に示す. 運動工 ネルギーが大きい\#1 の圧痕は，\#2 の圧痕に比べて大きい. \#1，\#2 ともに Step1 Step4 の試験方法により，圧痕が 試験体全面に付与されていることを確認した. 形状計測結果を図 11 に示す. 計測結果を円の方程式に Fitting（誤

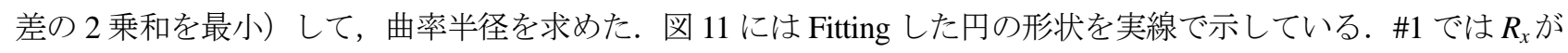
$9 \mathrm{~m}, R_{z}$ が $35 \mathrm{~m}$ であり, \#2 では $R_{x}$ が $24 \mathrm{~m}, R_{z}$ が $1.4 \times 10^{2} \mathrm{~m}$ であり, いずれの条件でも直方体ピンを用いることで, 
$R_{x}$ と $R_{z}$ が異なる曲率半径に成形できることを確認した. なお, \#1 の試験後にピンの先端形状を確認したところ, 先端半径が大きくなるような変形が生じていた，今後，ピンの材質について検討が必要である.

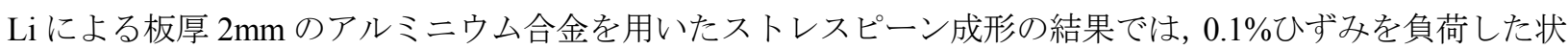

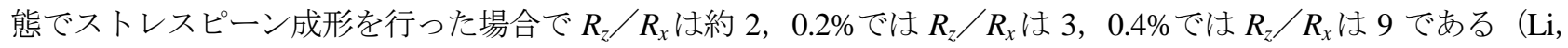
1981). Miao らによる板厚 $1.6 \mathrm{~mm}$ のアルミニウム合金を用いた結果では, $720 \mathrm{~mm}$ の曲げ半径を付与してストレ スピーン成形を行った場合では $R_{z} / R_{x}$ は約 $2,360 \mathrm{~mm}$ の曲げ半径を付与した場合では $R_{z} / R_{x}$ は約 $3,240 \mathrm{~mm}$ の曲 げ半径を付与した場合では $R_{z} / R_{x}$ は約 5 である（Miao et al., 2010). 本研究では民間航空機主翼で最大板厚を想 定した板厚 $10 \mathrm{~mm}$ のアルミニウム合金を用いたが， $R_{z} / R_{x}$ は\#1 で約 4, \#2 で約 6 であり, 板厚が薄い従来のス トレスピーン成形と同等の曲率半径の異方性を付与できており, 主翼の成形に適用できることを確認した．この ような予備曲げ付与が難しい厚板でも簡易に曲率半径の異方性を付与できることが本工法の特徴である.また， 複数のピンを用いて成形が可能であり, 今後, USP に展開することで, 効率の良い成形方法とすることが可能で ある.

曲率半径の異方性 $\left(R_{x}<R_{z}\right)$ の実験結果は図 3 図 6 に示した解析結果の塑性ひずみの異方性 $\left(\varepsilon_{x}>\varepsilon_{z}\right)$ と同じ傾 向である. すなわち, 塑性ひずみが大きい $x$ 方向に大きく変形するため, 曲率半径にも異方性 $\left(R_{x}<R_{z}\right)$ が発生 した. 図 3 図 6 に示したように, ピン先端形状で $\varepsilon_{x} / \varepsilon_{z}$ を変えることが可能であり, ピン先端形状で曲率半径の 異方性を制御できる可能性を示唆している. また, \#1 と\#2では曲率半径の異方性 $\left(R_{x}<R_{z}\right)$ は同じであるが, 運 動エネルギーが大きい\#1 の方が $R_{x}, R_{z}$ ともに小さくなっており, 運動エネルギーを制御すれば, 曲率半径も変わ ることを示している.

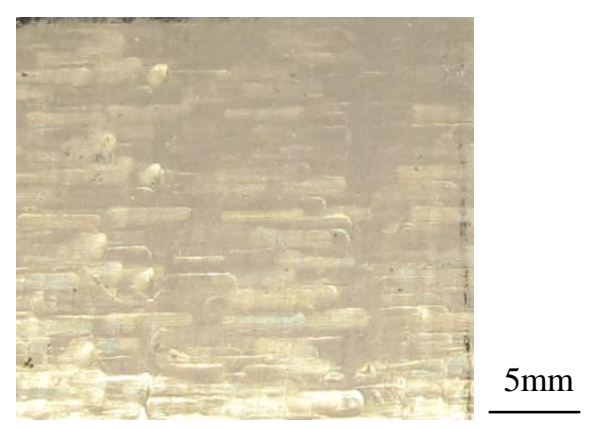

(a) Test\#1

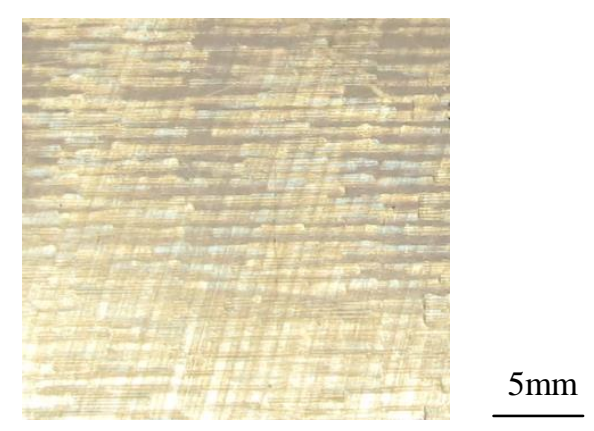

(b) Test\#2

Fig. 10 External view photographs of test pieces after drop tests.

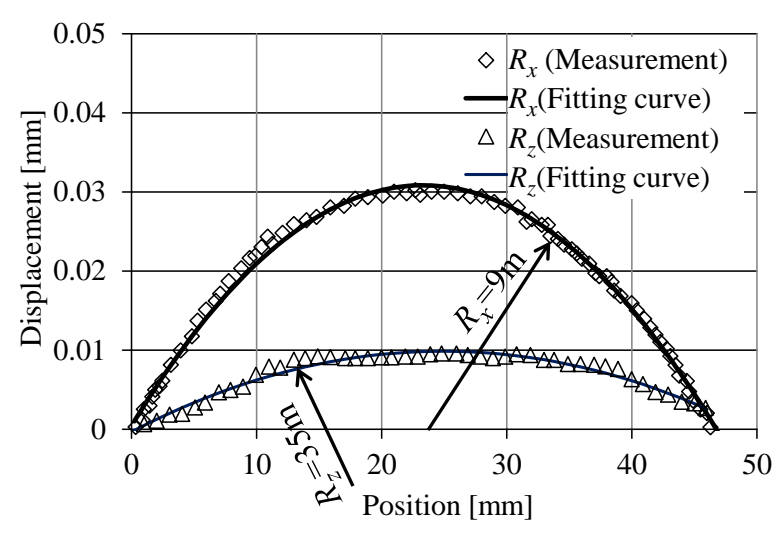

(a) Test \#1

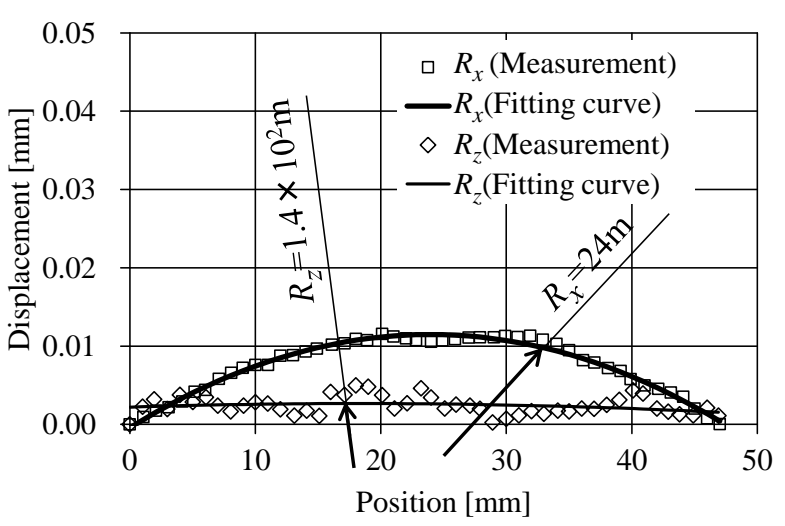

(b) Test \#2

Fig. 11 Measurement results of test pieces after drop tests.

\section{6. 結 言}

ピーン成形において, 直方体ピンを用いた場合の塑性ひずみの異方性を動的陽解法有限要素法で解 
析するとともに，複数の直方体ピンを用いた落下試験を行った．

1）直方体ピンを用いた場合，ピンの長辺方向（z方向）の塑性ひずみ $\varepsilon_{z}$ と短辺方向（ $x$ 方向）の塑性ひずみ $\varepsilon_{x}$ に異方性 $\left(\varepsilon_{x}>\varepsilon_{z}\right)$ が生じることを解析で確認した．ピン先端半径 $R$ について $4 \mathrm{~mm} \sim 12 \mathrm{~mm}$ で解析した結果, $R$ が小さいほど，圧痕直下に発生する塑性ひずみは大きく，塑性ひずみの異方性 $\left(\varepsilon_{x} / \varepsilon_{z}\right)$ が大きくなる傾向があ った.

2）民間航空機主翼で最大板厚を想定した板厚 $10 \mathrm{~mm}$ のアルミニウム合金に対して，先端半径 $R=4 \mathrm{~mm}$ のピンを 用いて，複数ピンの落下試験を行った結果，ピンの長辺方向（ $z$ 方向）の曲率半径 $R_{z}$ と短辺方向（ $x$ 方向）の 曲率半径 $R_{x}$ に異方性 $\left(R_{x}<R_{z}\right)$ が生じることを確認した. 曲率半径の異方性 $R_{z} / R_{x}$ は約 4 6であり，板厚が 薄い従来のストレスピーン成形と同等の曲率半径の異方性を付与できており, 主翼の成形に適用できることを 確認した. 予備曲げ付与が難しい厚板でも簡易に曲率半径の異方性を付与できることが本工法の特徴である. 今後，本工法は超音波ピーニングへ展開を行う予定である.

謝辞

本研究をお手伝い頂いた東海大学卒研生の宮本崇宏，加藤伸之輔の両君に感謝を申し上げる.

\section{文献}

Baughman, D. L., Peen forming, Machine Design Vol.42(1970), pp.156-160.

Clausen, R. and Bruder, M., Peen forming by pointed ball shooting (ball shot forming), Proceedings of the 3rd International Conference on Shot Peening(ICSP-3) (1987), pp.319-326.

Kopp, R., Kugelstrahlumformen, neuere Technologische und Theoretische entwicklungen, Proceedings of the 2nd International Conference on Shot Peening(ICSP-2) (1984), pp.6-14 (in German).

Kopp, R., Wüstefeld, F. and Linemann, W., High precision shot peen forming, Proceedings of the 5th International Conference on Shot Peening(ICSP-5) (1993), pp.91-102.

黒井邦宏，河野亮，小﨑貴史，半田充，佐々木省悟，航空機主翼外板への超音波ピーン成形技術の適用，第 48 回飛行機シンポジウム講演論文集(2010)，PaperNo.3C9.

$\mathrm{Li}, \mathrm{K}$., Using stress peen forming process for integrally stiffened wing panels, Proceedings of the 1st International Conference on Shot Peening(ICSP-1) (1981), pp.555-564.

Miao, H. Y., Demers, D., Larose, S., Perron, C. and Lévesque, M., Experimental study of shot peening and stress peen forming, Journal of Materials Processing Technology, Vol.210(2010), pp.2089-2102.

太田高裕, 超音波ピーニング処理における残留応力分布に及ぼすピン先端曲率半径の影響の数值解析, 塑性と加 工, Vol.58, No.672 (2017), pp.35-40.

Rousseau, T., Hoc, T., Gilles, P. and Nouguier- Lehon, C., Effect of bead quantity in ultrasonic shot peening: Surface analysis and numerical simulations, Journal of Materials Processing Technology, Vol. 225(2015), pp.413-430.

高橋孝幸, 山田毅, 石川孝司, ピーン成形の有限要素解析手法に関する研究, 塑性と加工, Vol.48, No.553 (2007), pp.120-124.

Thuemmler, P. , Polanetzki, H. and Schulze, V., Simulation of the ultrasonic shot peening process, Proceedings of the 10th International Conference on Shot Peening(ICSP-10) (2008), Paper No.2008113.

Yamada, T., Takahashi, T., Ikeda, M., Sugimoto, S. and Ohta, T., Development of shot peening for wing integral skin for Continental Business Jet, Mitsubishi Heavy Industries, Ltd. Technical Review Vol.39, No.2 (2002), pp.57-61.

\section{References}

Baughman, D. L., Peen forming, Machine Design Vol.42(1970), pp.156-160.

Clausen, R. and Bruder, M., Peen forming by pointed ball shooting (ball shot forming), Proceedings of the 3rd International Conference on Shot Peening(ICSP-3) (1987), pp.319-326.

Kopp, R., Kugelstrahlumformen, neuere Technologische und Theoretische entwicklungen, Proceedings of the 2nd 
International Conference on Shot Peening(ICSP-2) (1984), pp.6-14 (in German).

Kopp, R., Wüstefeld, F. and Linemann, W., High precision shot peen forming, Proceedings of the 5th International Conference on Shot Peening(ICSP-5) (1993), pp.91-102.

Kuroi, K., Kono, A., Kozaki, T., Handa, M. and Sasaki, S., Application of ultrasonic peen forming for wing integral skin for airplane, Proceedings of the 48th Aircraft Symposium (2010), PaperNo.3C9 (in Japanese).

$\mathrm{Li}$, K., Using stress peen forming process for integrally stiffened wing panels, Proceedings of the 1st International Conference on Shot Peening(ICSP-1) (1981), pp.555-564.

Miao, H. Y., Demers, D., Larose, S., Perron, C. and Lévesque, M., Experimental study of shot peening and stress peen forming, Journal of Materials Processing Technology, Vol.210(2010), pp.2089-2102.

Ohta, T., Numerical analysis of effect of pin tip radius on residual stress distribution in ultrasonic impact treatment, Journal of the JSTP, Vol.58, No.672(2017), pp.35-40 (in Japanese).

Rousseau, T., Hoc, T., Gilles, P. and Nouguier- Lehon, C., Effect of bead quantity in ultrasonic shot peening: Surface analysis and numerical simulations, Journal of Materials Processing Technology, Vol. 225(2015), pp.413-430.

Takahashi, T., Yamada, T, and Ishikawa, T., Deformation analysis of peen forming by finite element method, Journal of the JSTP, Vol.48, No.553(2007), pp.120-124 (in Japanese).

Thuemmler, P. , Polanetzki, H. and Schulze, V., Simulation of the ultrasonic shot peening process , Proceedings of the 10th International Conference on Shot Peening(ICSP-10) (2008), Paper No.2008113.

Yamada, T., Takahashi, T., Ikeda, M., Sugimoto, S. and Ohta, T., Development of shot peening for wing integral skin for Continental Business Jet, Mitsubishi Heavy Industries, Ltd. Technical Review Vol.39, No.2 (2002), pp.57-61. 